\title{
RESEARCH OF CURRENT MEANS OF COMPENSATING HIGHER HARMONICS OF CURRENT AND CAPACITY IN THREE-PHASE SYSTEMS
}

\section{N. Tretyak, Su Hongsheng}

nsheng

vul. Anning Xi, 88, Gansu province, People republic of China.

E-mail: kotya_hope@mail.ru; solo_brat@mail.ru

Purpose. To investigate the operation of three-phase electric motor of electric networks which is characterized by the absence of such capacity components such as reactive power and variable components of the active capacity as well as higher harmonics caused by asymmetry and harmonicas of the load. These undesirable components significantly decrease the efficiency of the energy transfer and transformation. Methodology. General scientific methods have been used. Thus, existence of higher harmonics and a variable component in the consumed three-phase capacity decrease efficiency of the electromechanical energy transformation from the point of view of the consumed electric energy into the mechanic one with the use of three-side electric drive. Results. The following results have been revealed. Harmonics are known to cause such serious problems as decreasing efficiency of energy consumption; overheating cables, electric motors and transformers; response of automatic switches; overheating and breaking down of capacitors; overloading neutral wires. Originality. Nowadays, the task of compensating higher harmonics components of the current remains topical. The active harmonics capacitor connected to the parallel non-linear load is one of the most widespread means of compensating higher harmonics of the current. Voltage oscillation is referred to as fast changes of the efficient value of the voltage that occur with the speed of 1-2\% of the normal voltage per second. Normalization of the voltage oscillations is done on the level of the influence on the human sight. Let us study the process of healthy perception of the oscillation (flicker). Practical value. The upper limit of the voltage oscillation that influences the sight with taking into consideration the constant time of the bulb filaments equals around $35 \mathrm{~Hz}$ with changes of voltage less than $10 \%$. The operation principle of the active harmonics capacitor is based on the analysis of current harmonics of non-linear load and generation of these current harmonics into the distributing net but with the reverse phase. References 17, figures 3 .

Key words: reactive power, active capacity, active harmonics, transformation, electromechanical energy, threephase capacity, voltage oscillations.

\section{АНАЛІЗ ІСНУЮЧИХ ЗАСОБІВ КОМПЕНСАЦЇ̈ ВИЩИХ ГАРМОНІК СТРУМУ ТА ПОТУЖНОСТІ В ТРИФАЗНИХ СИСТЕМАХ}

\section{Н. М. Третяк, Су Хоншен}

Ланджоуський транспортній університет

Аннин Си Лу 88, Провінція Ганьсу, Китайська народна республіка.

E-mail: kotya_hope@mail.ru; solo_brat@mail.ru

Проаналізовано роботу трифазних електричних мереж, що характеризується присутністю неактивних складових потужності, таких як: реактивна потужність та змінні складові активної потужності, а також вищі гармоніки, що викликані не симетрією або несинусоїдністю навантаження. Аналіз виявив, що небажані складові значно знижують ефективність передачі та перетворення енергії. Так, із погляду на перетворення спожитої електричної енергії в механічну із використанням тиристорного електропривода, наявність вищих гармонік та змінної складової в споживаній трифазній активній потужності знижує ефективність електромеханічного перетворення енергії. В роботі зазначено, що гармоніки приводять до серйозних проблем таких як: зниженню ефективності енергоспоживання; перегріву кабелів, електродвигунів та трансформаторів; спрацьовуванню автоматичних вимикачів; перегріву й виходу з ладу конденсаторів; перевантаження нейтральних проводів. Тому на сьогоднішній день не втрачає своєї актуальності задача компенсації вищих гармонійних складових струму. Наразі найпоширенішим засобом компенсації вищих гармонік струму є активний кондиціонер гармонік, що підключається паралельно нелінійному навантаженню. Принцип дії активного кондиціонера гармонік заснований на аналізі гармонік струму нелінійного навантаження і генерування в розподільну мережу тих же гармонік струму, але 3 протилежною фазою. Проблема якості електроенергії в цей час є дуже гострою. У першу чергу це викликано тим, що експлуатовані мережі фізично й морально застаріли, а інвестиції на їхнє відновлення недостатні. Навантаження на які вони були розраховані, за останні кілька років зросли в 1,5-2 рази. Необхідно також згадати, що електрифікація в Україні, проводилася прискореними темпами, що не могло не відобразитися на якості мереж і встановлюваного встаткування. Всі ці причини не можуть, не викликати зниження якості електроенергії. Ця проблема дуже гостро коштує перед багатьма підприємствами які розширюються й установлюють сучасне, найчастіше закордонне, устаткування, що в умовах низької якості електроенергії вимагає установки потужних стабілізаторів напруги.

Ключові слова: реактивна потужність, активна ємність, активні гармоніки, трансформація.

PROBLEM STATEMENT. The problem of the energy quality is very burning nowadays. First, it is caused by the fact that the exploited nets are physically and morally out-of-date and there are no efficient invest- ments into their renovation. The loads, they were calculated for, have increased in 1,5-2 times. It is worth mentioning that electrification in Ukraine was speeded up that could not help but influence the quality of the nets 
and the installed equipment. The equipment (transformers, high-voltage switches, capacitors) having 30-40 years of service time have been still exploited.

In such conditions the control of the electric energy quality is conducted only by consumers who have enough material resources for it while the transferring companies control only the consumption of the reactive power.

According to the International standard, the main indexes and norms of the electric energy quality in the electric networks of the system of electric supply of common purpose of a variable three-phase and onephase current with frequency of $50 \mathrm{~Hz}$ in the points to which the electric nets are connected or electric energy receivers are the following: voltage oscillation, nonsinusoidal voltage, voltage asymmetry, frequency error, voltage depression, voltage impulses, temporary overvoltage

All these reasons cannot but cause decrease of the electric energy quality. This problem is burning among many enterprises developing and installing up-to-date (most often foreign) equipment that in current conditions of the low electric energy quality requires installation of the powerful voltage regulators.

In the exploitation practice, it is considered that the operation efficiency of all electric equipment and especially the systems of the electric drive using alternating current electric energy is mainly determined by the electric energy quality in the supply nets.

Voltage oscillation is referred to as fast changes of the efficient value of the voltage that occur with the speed of $1-2 \%$ of the normal voltage per second. Normalization of the voltage oscillations is done on the level of the influence on the human sight. Let us study the process of healthy perception of the oscillation (flicker). The upper limit of the voltage oscillation that influences the sight with taking into consideration the constant time of the bulb filaments equals around $35 \mathrm{~Hz}$ with changes of voltage less than $10 \%$. The sensitiveness of the human visual perception of the light oscillation depends on the frequency and can be between 8 and $10 \mathrm{~Hz}$ maximum. The relation between the relative amplitude of the voltage change and the corresponding flicker feeling is quadratic, i.e. increase of the visual perception takes place faster that the increase of the voltage oscillations. Another parameter concerning the reaction of the sight system is the effect of remembering everything that happens in the brain.

Harmonics cause such serious problems as decreasing efficiency of energy consumption; overheating cables, electric motors and transformers; response of automatic switches; overheating and breaking down of capacitors; overloading neutral wires.

MATERIAL AND RESULTS. To choose the approach to compensating higher harmonics, we need to study the main means of controlling them that are applied in modern electrical engineering.

Switching in the linear throttle.

Consecutive switching in the linear throttles is the simplest way to decrease higher current harmonics into the out net. Such throttle has the value of the induction resistance on the main frequency $50 \mathrm{~Hz}$ and significant value of resistance for higher harmonics that leads to their weakening.

Applying passive filters.

Application of the consecutively connected linear throttles in a range of cases does not allow decreasing the current harmonic distortions to the appropriate limits. In this case, it is reasonable to use the passive $L C$-filters adjusted for a certain harmonic order. To improve harmonic component of the consumed current, such filters are widely applied in the systems with the sources of uninterrupted power supply (UPS). Connection of the filter on the input of the six-half period rectifier with $100 \%$ UPS load ensures decreasing of the current distortion coefficient to the value of $8-10 \%$. The value of the coefficient in the system without filters can reach $30 \%$ and above.

Application of special isolating transformers.

The isolating transformer with the winding "triangular-star" allows efficiently control harmonics multiple of three with the balances load. The crossing (zigzag) system of winding where the secondary winding of each phase is divided into two parts and places on different rods of the transformer magnetic conductor is used for weakening the influence of the load asymmetry and decreasing the neutral terminal current. On nonsinusoidal current the losses increase in transformers mainly due to the loses on Foucault currents that requires increase of their established capacity or application of special K-factor transformers. K-factor transformers differ from the standard ones with having additional heat capacity allowing standing heating caused by the current higher harmonics. Besides, a special constriction of such transformer allows minimizing expenses on Foucault currents and expenses because of the spurious capacitance.

Applying magnetic synthesizers.

The magnetic synthesizer ensures protection of the load from various distortions of electric supply, i.e. from voltage depressions and voltage surges, impulse and high frequency obstructions, existence of higher harmonics that causes distortions of the sinusoid form of the outgoing voltage. The outgoing voltage of the magnetic synthesizer on each half-period of the main frequency is generated by combining six rectangular impulses connected from the transformers with saturation connected with each other like the investors with stepped control principle. Although the magnetic synthesizer does not contain any power half-conducting elements performing the function of the voltage stabilizer.

Nowadays there are several capacity theories, which suggest mathematical description and treatise of the capacity components in electric circuits with valve inverters. It is worth noting that the accurate solution of the task of harmonic compensation is possible due to:

- the knowledge of exploitation conditions and technical characteristics of the energy sources, distribution system and power service protector;

- the accurate knowledge of loads (harmonic constituents of the current, consuming capacity, place of their connection in the energy supply system);

- the usage of special measuring equipment for experimental determination of the harmonic constituents 
of the current on different parts of the energy supply distribution system.

It is obvious that the correct adjustment and calculation of the currents of compensation require distinct and true, physically and mathematically proved information on the components of the capacity in threephase electric rings.

The active harmonic conditioner connected parallel to the non-linear load is one of the most widespread means of compensating higher harmonics of the current.

The operation principle of the active harmonic conditioner is based on the analysis of current harmonics of non-linear load and generation of these current harmonics into the distributing net but with the reverse phase. As a result, higher harmonic constituents of the current are neutralized in the connection point of active harmonic conditioner. It means that they do not spread from the non-linear load into the net and do not distort the current of the primary voltage source

Their classification and the main sense are given in the works. Now we can determine three capacity theories that are widely used for interpreting components of three-phase capacity and, as a result, suggest strategies of compensating the mentioned inappropriate harmonics: Cross-vector theory, $\mathrm{p}-\mathrm{q}$ theory of instantaneous power and p-q-r theory of instantaneous power. Although the analysis of the above-mentioned theories is given many times, it is worth mentioning that their main propositions, advantages and disadvantages. The main propositions according to which one can characterize these theories are various determinations of the active and reactive capacities of the three-phase system.

$P-q$ theory of the instantaneous reactive power.

$\mathrm{P}-\mathrm{q}$ theory of the instantaneous reactive power is presented in the work as a fundamental theory for analysing features and physical processes in three-phase systems, for application on solving problems relating to higher harmonics, reactive power and asymmetry, for calculation and control of the active filters. This theory envisages transfer from the stationary system of coordinates $A-B-C$ to the stationary system of coordinates $\alpha-\beta$ based on the Clark's transformation. Hereby one should notice that in the given theory the term «instantaneous unreal power» is a synonym to the term «instantaneous reactive power» and is determined as a part of the sum of instantaneous three-phase voltages and currents that does not perform any transfer of energy from one system to another one in any time. Moreover, the physical essence given to these values equals the following: it is a part of the energy, which the system phases exchange.

Hereby one should notice that in the given theory the term «instantaneous unreal power» is a synonym to the term «instantaneous reactive power» and is determined as a part of the sum of instantaneous three-phase voltages and currents that does not perform any transfer of energy from one system to another one in any time. Moreover, the physical essence given to these values equals the following: it is a part of the energy, which the system phases exchange.

Some authors believe that the disadvantage of $p-q$ theory of instantaneous power is the lack of opportunity of its application when analysing three-conductor nets with zero wire and, in a range of cases, big values of coefficients of unsinusoidality of the current after their PAF correction on the nonsinusoidal net voltage. Although, in the range of literature sources the author finds and states other disadvantages of the studied theory and even some discrepancy with the physical sense.

According to some sources instantaneous and reactive $p-q$ powers in the sense suggested do not allow identify immediately all the processes of transforming electric energy in the three-phase net. Firstly, instantaneous active power $p$ is nothing else but an instantaneous power - value of the energy flow from the source of supply to the load. Also believes that two names for the same value can cause some obscurity and, what is the most important, the value $p$ is not related to the active power $P$ of the load. Thus, it exists independently of the fact whether the load had an active power or not. Similar obscurities appear when reviewing instantaneous power $q$ and its physical content. Reactive elements in the load are not responsible for appearance of $q$, since it appears even in the clearly active load. The results of the conducted modelling prove the remarks to the theory are well founded: according to the expressions suggested in some sources, in the three-phase system with zero wire the «imagined» (i.e. calculated) reactive power that does not comply with the physical content.

In general, according to the theory of electromagnetic fields, the instantaneous reactive power $q$ cannot be presented as energy the net phases exchange with.

At the same time, many authors state the false thesis of the $p-q$ theory that the variable component of the active power is always undesirable. It is supposed, if the source voltage is asymmetrical but does not include the main and, for example, the fifth harmonics, so the power transferred to the load in the result will comprise constant and variable components with the frequency exceeding the net frequency in six times. Since the load is exceptionally active, this variable component will not influence its power coefficient in any way, i.e. the active power equals the full (imagined) power. In addition, there is no need in compensating this variable constituent in the result of it. This statement is fully proved because:

- when calculating the content of the instantaneous power not all higher harmonics that appear in the spectrum of the instantaneous power when feeding from the polyharmonic supply source are considered;

- expediency of compensating the variable components of the three-phase power should be assessed not only from the point of view of the value of the reactive power in the system, since higher harmonics of the power can influence not only the coefficient of the load power - vibration and additional loses in the rotary machines, increase of expenses in transformers, worsening the operation of electric system protection devices, etc 


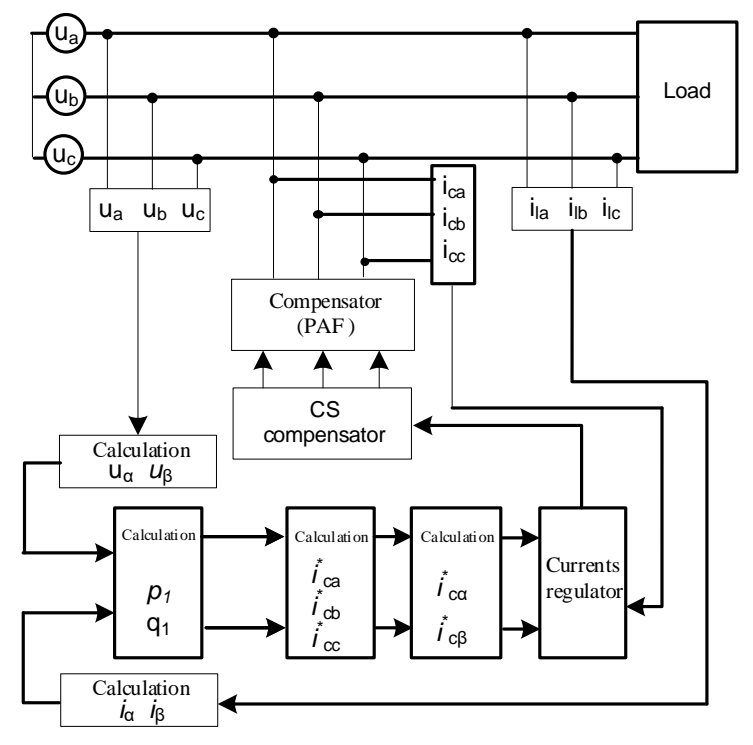

Figure 1 - Diagram of compensating higher harmonics of the load current and the reactive power realized based on the $p$ - $q$ theory

Using $p$ - $q$ theory we can independently regulate on the zero and phase currents, but we need to have an active energy accumulator since instantaneous powers and interdependent.

$p$-q-r theory of power.

This theory uses three systems of coordinates: $a-b-c$, $\alpha-\beta-0$ and $p-q-r$, the first two are motionless relating to each other, and the third system $p-q-r$ rotates round the axle 0 together with plane that is perpendicular to the plane $\alpha-\beta$. Position of the axle $p$ is determined with the load vector $u_{\alpha \beta}$ in the plane $\alpha-\beta$ and the load vector of the zero sequence.

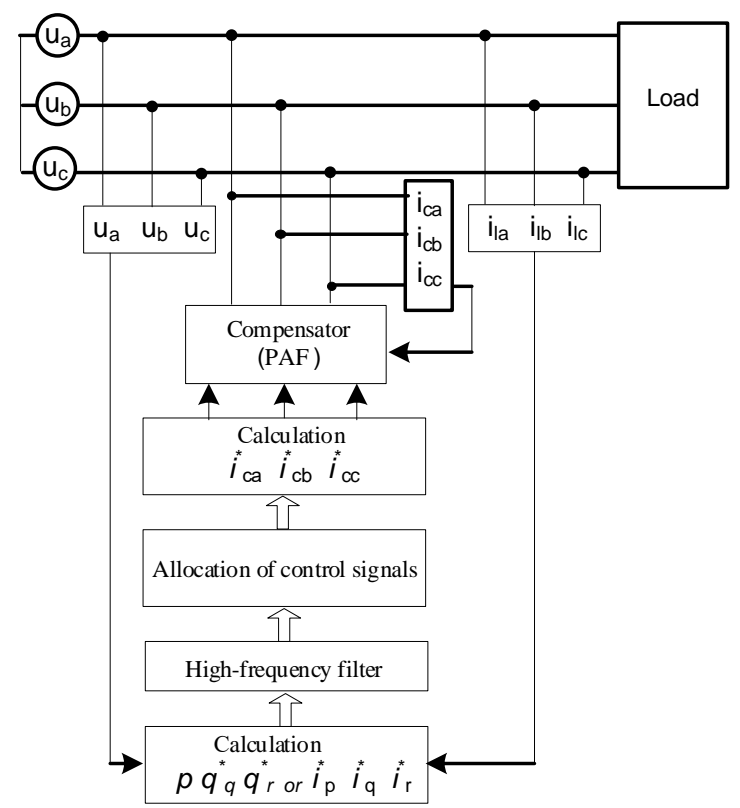

Figure 2 - Diagram of compensating higher harmonics of the load current and the reactive power realized based on the p-q-r theory
The advantage of this theory is its ability to suggest calculation of powers that depend on each other linearly. The main disadvantage of this theory is in case of distorted and asymmetrical voltages of the net with the part of variable components in the instantaneous active and reactive powers remain uncompensated even when the currents in the net remain symmetrical and sinusoidal. The PAF control system built based on $p-q-r$ theory allows regulating separately zero and phase currents without energy accumulator but even if the net currents are sinusoidal and symmetrical, a part of the variable components in the instantaneous active and reactive powers remains uncompensated. Considering that, the three components of the current can be compensated with three independent regulators without the energy accumulator.

\section{Cross-vector theory.}

Cross-vector theory or «generalized theory of instantaneous reactive power» can be applied to calculate both sinusoidal and nonsinusoidal three-phase systems with or without voltage/current of zero sequence. We suggest the scheme of the device for compensating the reactive power of the load current harmonics based on the cross-vector theory. The compensator is suggested to be made based on the voltage inverter with wide-impulse modulation connected parallel to the load. The results of the modelling prove the efficiency of the compensation system of harmonics, reactive power and currents in the zero wire with the help of the control schemes built based on cross-vector theory.

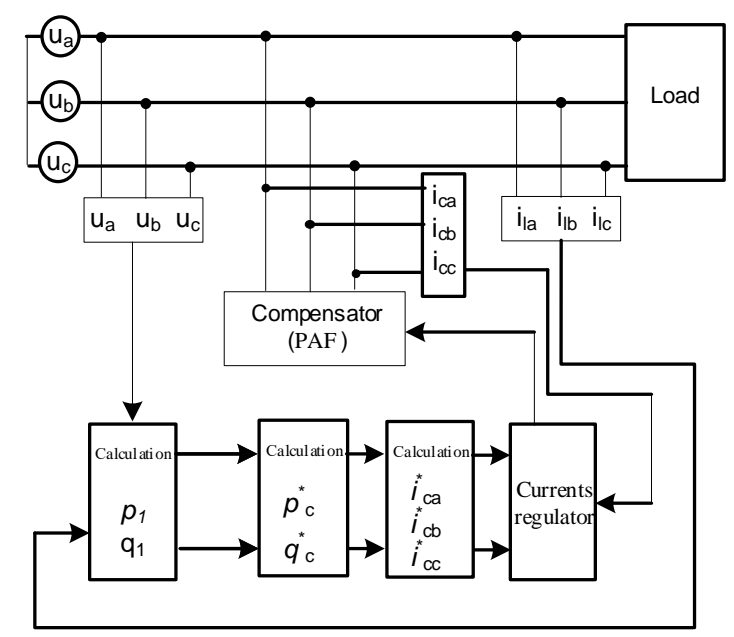

Figure 3 - Diagram of compensating higher harmonics of the load current and the reactive power realized based on the cross-vector theory

As shown in the work, the results of the modelling prove the efficiency of the compensation system of harmonics, reactive power and currents in the zero wire with the help of the control schemes built based on cross-vector theory.

Cross-vector theory does not allow controlling currents in the zero wire independently on the phase ones and does not ensure full compensation of the current in the zero wire if the currents have zero sequence. 
The main differences of the described theories lie in their efficiency when compensating currents in the zero wire on nonsinusoidal and asymmetrical net loads:

- cross-vector theory does not allow controlling currents in the zero wire independently on the phase ones and does not ensure full compensation of the current in the zero wire if the currents have zero sequence;

- using $p$ - $q$ theory we can independently regulate on the zero and phase currents, but we need to have an active energy accumulator since instantaneous powers interdependent;

- the PAF control system built based on $p-q-r$ theory allows regulating separately zero and phase currents without energy accumulator but even if the net currents are sinusoidal and symmetrical, a part of the variable components in the instantaneous active and reactive powers remains uncompensated.

CONCLUSIONS. Quality of electric power determined with the amplitude, frequency and distortions of the form of the signal from the supply system. While the amplitude and the supply frequency are determined by energy-supplying companies, the wave form (of the voltage or current) is distorted by consumers (of the power) or loads. Linear loads as well as asynchronous engines, electric bulbs, resistive heating devices or capacitor banks consume sinusoidal current that is in accordance to the wave of the power supply. On the other hand, nowadays most typical loads are non-linear, for example VSD (variable-speed drive), equalizers, sources of non-stop supply, computers, TV sets, energy saving (fluorescent) lamps, photocopying machines, etc. These loads consume the source current that does not correspond to the form of the voltage wave and distort its form. Distortions are caused by harmonics formed with non-linear devices. These harmonics are an increasing problem for suppliers and consumers of the electric energy.

The active harmonics capacitor connected parallel to the non-linear load is one of the most widespread means of compensating higher harmonics of the current. The operation principle of the active harmonic conditioner is based on the analysis of current harmonics of non-linear load and generation of these current harmonics into the distributing net but with the reverse phase. Nowadays there are several capacity theories, which suggest mathematical description and treatise of the capacity components in electric circuits with valve inverters. On the current stage, we can differentiate three theories of power: cross-vector theory, $\mathrm{p}-\mathrm{q}$ theory of instantaneous power and $p-q-r$ theory of instantaneous power.

\section{REFERENCES}

1. Zhezhelenko, I. V. (1997), Issues of electric energy quality in electric plants, Mariupol: PSTU, 173 p.

2. Zhezhelenko, I. V. (1981), Electric energy quality on manufacturing enterprises, Kyiv: Technics, 160 p.
3. Domnin, I. F., Zhemerov, H. H., Krylov, D. S., Sokol, E. I. (2014), Modern theories of capacity and their application in transformation systems of power electronics, Technical electrodynamics, pp. 80-91.

4. Leszek, S. (2006), Czarnecki Instantaneous reactive power $\mathrm{p}$-q theory and power properties of threephase systems, Transactions on Power Delivery, vol.21, no.1, January, pp. 362-367.

5. Leszek, S. (2009), Czarnecki Comments to the paper: Instantaneous p-q theory for compensating nonsinusoidal systems, ISSN 0033-2097, R. 85, pp. 167169.

6. Akagi, H., Kanazawa, Y., Nabae, A (1983), Generalized theory of the instantaneous reactive power in three-phase circuits, IPEC'83, Tokyo, Japan, pp. 13751387.

7. Dugan, R. C., McGranaghan, M. F., Beaty, H. W. (1997), Electrical Power Systems Quality, McGrawHill, 265 p.

8. Fiorina, J. N. (2000), Inverters and Harmonics, Cahier Technique Merlin Gerin, no 159, 99 p.

9. Yacamini, R. (1995), Power System Harmonics. Part 3 - Problems caused by distorted supplies, Power Engineering Jounal, pp. 233-238.

10. Harmonic Disturbances in Networks and Their Treatment (2011), Cahier Technique Schneider Electric, no $152,25 \mathrm{p}$.

11. Kim, H. S., Akagi, H. (1999), The instantaneous power theory on the rotating p-q-r reference frames, Proc. IEEE/PEDS'99 Conf., Hong Kong, July, pp. 422-427.

12. Peng, Z., Ott, G. W., Adams, D. J. (2012), Harmonics and reactive power compensation based on the generalized instantaneous reactive power theory for three-phase four-wire systems, IEEE Trans. Power Electronics, vol.13, no 6, pp. 1174-1181.

13. Akagi, H., E. Watanabe, H., Aredes, M. (2012), Instantaneous power theory and applications to power conditioning, IEEE Press on power engineering, Canada, $379 \mathrm{p}$.

14. Afonso, Joao L. (2003), P-Q power components calculations, ISIE 2003 - IEEE International Symposium on Industrial Electronics. - Rio de Janeiro, Brazil, 9-11 June, pp. 261-265.

15. Kolb, A. A. (2015), Combined symmetrising compensating devices with the use of parallel active filters, Topic issue of the scientific-technical journal "Electroinform": "Problems of automatic electric drive" Theory and practice, Lviv, EKOinform, pp. 365-367.

16. Zhemerov, H. H., Sokol, E. I., Krylov, D. S., Baru, A. Yu., Shyndnes, Yu. L.(2013,) Computer modelling of the transformation system with compensating controlled rectifie, part 4, pp. 59-62.

17. Klimov, V. P., Moskalev, A. D. (2009), Problems of higher harmonics in modern electric supply systems, pp 62-66.

\section{АНАЛИЗ СУЩЕСТВУЮЩИХ СРЕДСТВ КОМПЕНСАЦИИ ВЫСШИХ ГАРМОНИК ТОКА И МОЩНОСТИ В ТРЕХФАЗНОЙ СИСТЕМЕ}

\section{Н. М. Третьяк, Су Хоншен}

Ланджоуский транспортный университет

Аннин Си Лу, 88, Провинция Ганьсу, Китайская народная республика.

E-mail: kotya_hope@mail.ru; solo_brat@mail.ru 
Изучена работа трехфазных электрических сетей, что характеризуется присутствием неактивных составляющих мощности, таких как: реактивная мощность и переменные составляющие активной мощности, а также высшие гармоники, вызванные не симметрией или несинусоидальностью нагрузки. Анализ показал, что эти нежелательные составляющие значительно снижают эффективность передачи и преобразования энергии. Таким образом на преобразование потребленной электрической энергии в механическую с использованием тиристорного электропривода, наличие высших гармоник и переменной составляющей в потребляемой трехфазной активной мощности снижает эффективность электромеханического преобразования энергии. В роботе было определено, что гармоники приводят к серьезным проблемам, таким как: снижению эффективности энергопотребления; перегрева кабелей, электродвигателей и трансформаторов; срабатыванию автоматических выключателей; перегрева и выхода из строя конденсаторов; перегрузки нейтральных проводов. Поэтому на сегодняшний день теряет свою актуальность задача компенсации высших гармонических составляющих тока. Анализ определил, что самым распространенным средством компенсации высших гармоник тока является активный кондиционер гармоник, подключающийся параллельно нелинейной нагрузке. Принцип действия активного кондиционера гармоник основан на анализе гармоник тока нелинейной нагрузки и генерации в распределительную сеть тех же гармоник тока, но противоположной фазой. Проблема качества электроэнергии в настоящее время является очень острой. В первую очередь это вызвано тем, что эксплуатируемые сети физически и морально устарели, а инвестиции на их восстановление недостаточны. Нагрузка на которую они были рассчитаны, за последние несколько лет выросли в 1,5-2 раза. Необходимо также упомянуть, что электрификация в Украине, проводилась ускоренными темпами, что не могло не отразится на качестве сетей и устанавливаемого оборудования.

Ключевые слова: реактивная мощность, активная емкость, активные гармоники, трансформация.

Стаття надійшла 14.05.2018. 